\title{
The "RETURN" OF PERFORMANCE ART FROM A GLOCAL PERSPECTIVE
}

Cláudia Madeira

ICS - Lisbon University

\begin{abstract}
Various authors have characterized the contemporary world through the notion of "structural hybridization" (Pieterse 2001; Canclini 2001, among others). This notion refers to the mixing of different times and spaces that gives rise to "spatiotemporal" hybrid configurations. One of the factors of this process is usually translated by the term "bybrid cycles" (Stross 1999), through which a new cycle recovers historical and social characteristics of previous cycles, sometimes distant in time. Through this theoretical framework, which combines concepts such as bybridity, cyclicality, mimesis, reflexivity and performativity, this paper intends to problematize issues such as the so-called "social turn" (Bishop 2006) or "return to the real" (Foster 2001) in art or, more generally, the "performative turn" (Alexander 2006), with the aim of analyzing the cyclical dynamic of performance (social) art (an art that relies on notions of participation and even performative intervention in a public space) from a global perspective - from Portugal to the world and vice versa.
\end{abstract}

Keywords: hybridity, cyclicality, mimesis, reflexibility, performativity.

\section{HYBRIDITY AND CYCLICITY}

In an essay entitled "Time" (2006:120), the sociologist Barbara Adam states that art, like myth and ritual, is one of the ways that allow the suspension of time. Art is a way of transmitting culture and accumulating knowledge, because it externalizes and fixes beliefs, experiences, expectations, fears and hopes in a form that can be shared (as well as variably interpreted) beyond the time in which it is composed.

However, with the exception of these areas (art, myth and ritual), Adam's theory is based on a linear notion of social time, "a one-way street" impossible to reverse in historical time 
because every event is new - a notion that follows the classical Aristotelian conception that defines time as "the number of movement" (Aristotle, On the Heavens, Part 9, quoted in Gurvitch 1986 (1968): 372). This was reformulated by Newton in 1687: "Absolute, true, and mathematical time, of itself, and from its own nature, flows equally without relation to anything external" (Kern 2003(1983):11). So the question that arises from Adam's theory is whether there is such a thing as suspended time and, therefore, the reversibility of time in these specific areas - art, myth and ritual — without the possibility of reversibility in daily and historic time.

One approach to these cyclical dynamics, from the perspective of "structural hybridism" or "globalization as hybridisation"1 (Pieterse 2001; Canclini 2001; Madeira 2010, among others), is based on Brian Stross's notion of "hybrid cycles" (1999). Hybrid cycles, which are always characterized by some degree of hybridity ${ }^{2}$, alternate between more and less heterogeneous forms, none of which can be considered as a simple reproduction of the process recovered. Also, these forms do not necessarily refer to an equal standard in all spheres of the social or even for all cultural contexts. In Stross's words: "One can (...) examine the larger diachronic process of what could be called a 'cycle of hybridity': a cycle that goes from 'hybrid' form, from relative heterogeneity, to homogeneity, and then back again to heterogeneity" (1999:265).

This paper aims to analyze the heuristics of "hybrid cycles", in order to explain the possible periodic correlation, in global and local contemporary scenarios of social and political crisis, between social demonstrations and artistic or quasi-artistic forms of expression (disseminated by artists as well as "the people") that occupy the streets. To reach this goal, the first part of this paper will analyze the origins and theoretical developments of this concept in relation to hybridity; the second part will proceed to its articulation with the notion of performativity; finally, in the third part, as a test of this cyclicality, we shall introduce the case of Portugal, from an empirical perspective, as a scenario of the glocal "return" of the correlation between the performativity of social protest and performative artistic or quasi-artistic expression extended to the streets.

Although the concept of "hybrid cycles", which repeat some parts of previous forms, has been set in a contemporary context of globalization, the notion of "historical cycles" has been employed at different times by various social science authors from diverse disciplines. (It can be compared to Mendel's theory - even with its limitations - of genetic reproduction and mutability, where, alongside dominant genes, there are recessive ones that only re-appear in the second or third generation.) For example, in his book The Myth of the Eternal Return (1969), the anthropologist Mircea Eliade quotes philosophers and historians such as Spengler, who published The Decline of the West in 1918, and Toynbee, who, between 1934 and 1961, wrote

1 "Structural hybridism", characterized by the intensification of hybrid things, objects and processes, crosses from the micro-scale to the macro-social scale, from hybrid social identities to the dynamics of "globalization as hybridization", and is based on a process that mixes different temporal (past, present and future) and spatial contexts. As Canclini (2001) states: due to the introduction of advanced technologies and modern and postmodern social processes, occurring especially at the borders of countries and in major cities (that promote fusions between local and mediatic cultures, between the consumption styles of different generations, between local and transnational music, etc.), the concept of hybridity has become more heuristic in the analysis of the dynamics of global fluxes (Hannerz, 1997) than notions of mestizaje, syncretism, creolization, etc. This structural hybridity therefore introduces a kind of "glocalism" developed under the maxim of "global thinking, local action".

2 Bruno Latour (1993) goes even further in this approach by proclaiming that "we have never been modern", which allows him not only to demystify the difference between modernity and postmodernity but also the idea of the existence of times without "mixing" and "hybridity". 
A Study of History. These authors also take this cyclicity as the focus of their analysis. But Eliade also quotes Pitirim Sorokin, a sociologist who, in 1937, in his work Social and Cultural Dynamics, defended the thesis that the most general pattern of socio-cultural change is that of incessantly varying recurrent processes, such as the phenomena of war and peace, stable and unsettled periods, revolution and reaction, autocracy and democracy, individualism and collectivism, classicism and romanticism, idealism and materialism, peace and anarchy, peak and decay, integration and disintegration (1957). In Sorokin's view, this meant that identical repetitive socio-cultural processes are impossible; perpetually linear socio-cultural processes are also impossible; a linear tendency (of varying durations), limited in time, is expected and is actually found in almost all socio-cultural processes, and so, history always repeats itself and never repeats itself; both of these seemingly contradictory statements are true and are in no way contradictory when properly (i.e., dialectically) understood. This means, in turn, he concludes,

that the strictly cyclical conception (repeated identically) of the socio-cultural processes; the unlimitedly linear conception; the unicist conception, in the sense of not having any repetitive rhythm in the "totally new" processes at any given moment; and the static conception, which governs the existence of change - all these conceptions of socio-cultural change are illusory. The valid conception is a continuous variation in the main themes repeated, containing in itself, as parts, all of these conceptions, and as such is richer than any of them $(1969: 577)^{3}$.

Eliade also quotes Nietzsche, who portrays Zarathustra as arguing that in the circularity of the eternal return "only the excess returns" (Deleuze 2000 (1969): 469). In his work Thus Spoke Zarathustra, when Nietzsche introduces us to the question of the "eternal return", he begins by telling us that historical time, the time of men, seems to roll on by itself in circular fashion. However, he also tells us, through Zarathustra, that in this circularity not everything returns: if a circle is formed it will only happen "at the end" of the straight line where there are different directions. And then, "Only the affirmative returns, this is the Different, the Dissimilar. (...) Nothing of that which denies the eternal return returns" (Deleuze 2000 (1969): 470) ${ }^{4}$. The "eternal return" thus implies selective and affirmative creation, not a return to the same and similar. For authors who believe in cyclical recurrence, this sentence summarizes the argument that this repeatability of history is not irreconcilable with the notion of historical evolution. As Sorokin puts it: "History always repeats itself and never repeats itself" (1969: 577).

More recently, other authors have followed a similar analysis by comparing the Middle Ages and/or the Baroque Age with contemporary time. For example, in 1974, Umberto Eco wrote an essay called "The New Middle Ages" (2004 [1974]). For Eco, there is a correspondence between the two periods (the old and the new Middle Ages) based on identical educational utopias and the same ideological guise of a paternalistic project to manage consciousness that tries to conceal the difference between high and popular culture through visual communication. From his perspective, both cultures (the two "Middle Ages") develop a taste for recompilation and inventory:

Now as then, minority and refined experimentation coexists with the big enterprise of popular dissemination (...) with reciprocal exchange (...): and the apparent Byzantism, the passionate taste for collection, by

3 So, for Sorokin "studying more and more different repeated social phenomena, we approach more and more to a solution of the great sociological problem: what in the incessantly changing process of history is relatively permanent, and what is quite temporary; what is relatively universal, and what is purely local; what relations between two or more phenomena are incidental, and which are really causal?” (1957:741)

4 Quotations in this article (where necessary) have been translated by the author. 
catalogue, by collage, and by the accumulation of different things is due to the requirement to decompose and return to judge the remains of an earlier, perhaps harmonic but already outdated world ... (op. cit.: 33).

In his book The Neo-Baroque Age, Omar Calabrese defines culture and contemporary art as an "aesthetic of repetition" that is produced inside social systems by centrifugal forces that lead to the amplification phenomena of "excess", affecting the contents, structures, forms, discourses and reception modes in general. According to this author, the fact that these centrifugal forces predominate inside, and not outside, social systems, leads to excess. They do not necessarily produce "social unacceptability" or rejection: "the boundaries of the systems, because of the 'acceptable' excess, are simply pushed away (even much further away than before), with consequent absorption, even conflicting, excess" (1999[1987]:79).

In the field of Performative Studies, Richard Schechner states in his 1995 book The Future of Ritual that our own time is in fact the beginning of a long neo-medieval period, or a neoHellenistic age ${ }^{5}$. In his own words:

Events today are recorded, replayed, ritualized, and recycled. (...) a long neo-medieval period has begun. Or, if one is looking for historical analogies, perhaps neo-Hellenistic is more precise. A certain kind of Euro-American cultural style is being extended, imposed, willingly received (the reactions differ) by many peoples in all parts of the world. Exactly what shape this style will take, what its dominant modes of thought will be, are not yet clear. But it will be a conservative age intellectually and artistically. That does not mean reactionary or without compassion. (...) It is a conservatism based on the need to save, recycle, use resources parsimoniously. It is founded on the availability of various in-depth 'archives' of many different prior experiences, artworks, ideas, feelings, and texts. This stored and recallable prior knowledge is being used to avoid repeating certain kinds of events as well as to promote certain new kinds of events (...) (1995: 19).

In sociology, Pieterse (2001b), one of the central theoretical authors of "structural hybridism", stresses the equivalence of the Middle Ages and today's world. In his article "Global Multiculture" (2001b), he retrieves the perspectives of Hedley Bull, who, in 1977, had already called attention to the emergence of a neo-medieval age of "overlapping authorities and crisscrossing loyalties"; of Calabrese (1987), who, as we saw above, characterized the postmodern condition as neo-medieval and postmodernism as a neo-baroque sensibility; and even of Kobrin, who, in 1998, asserted that information technology and cyberspace interactions signalled the start of a neo-medieval epoch.

Cyclical theories of time seem to be one of the specific signs of the Middle Ages, since it was precisely at the height of that period that these theories began to dominate historical speculation (Eliade, 1969), pointing towards a theory that explains the periodic return of events in cyclical waves. In 2003, accepting this perspective, Terry Eagleton noted a certain equivalence between pre-modernity and postmodernity, considering that what connects the two periods is that, for both, culture represents a transversal and dominant level of social life. As Eagleton states: "In fact one might claim that culture is a pre-modern and post-modern rather than modern idea; if it flourishes in the era of modernity, it is largely as a trace of the past or anticipation of the future" (2000:29). For this author, therefore, what connects the two orders is that for both, although for different reasons, culture is a dominant level of social life. In traditional societies the dominant role of culture is due to the fact that it is not so much a "level" as a framework within which other types of activity occur. The various areas of social systems are not really different. In the postmodern world, Eagleton tells us, culture and common life

5 Calabrese also mentions various "Baroque" periods in history: Pre-Classical Antiquity, Late Latin Culture, the Alexandrian Period, the Late Middle Ages, Mannerism and the Baroque (1999(1987):146). 
are again cross-linked, although this is expressed in other ways, e.g. through the aesthetics of style, fashion and advertising, or again through politics as a spectacle, the consumer lifestyle, the centrality of the image, and the ultimate integration of culture into the general production of goods.

Other theorists like Maffesoli (2001) and Giddens (1986 [1984]) have also analysed the reversibility of time, which is based on a permanent structure that simultaneously relates the past, present and future ${ }^{6}$ in an everyday approach. From this perspective, for Giddens, the most routine types of activity can be represented as a profile of time-space paths embedded in reversible time (1986 [1984], 36; 200; 282) and, for Maffesoli: "the cycle, or spiral, of destination follows the linearity of the story". In his book The Eternal Moment - The Return of the Tragic in Postmodern Societies (2001), Maffesoli says that this structural dimension of the repetition of actions in time devalues the "logic of disjunction (or ... or)", which permeates the "senses of separation, distinction and autonomy", in favour of the "logic of conjunction (and ... and)", which calls for "reversibility, mixing and heteronomy" (2001:11). Maffesoli supports this approach to notions such as "return", "regression" (psychology), "reverse" (Durand), "return, a piling-up of the past" (P Sorokin), and the "long memory of the collective unconscious" / "nonsimultaneity" (Bloch).

In sum, this perspective underlines not only the possibility of a "linear time" and a "cyclical time", but also a "plurality" and even "simultaneity" of times, which is justified by the replacement of a Newtonian perspective with an Einsteinian one based on relativity: "With relativity, temporal pluralism emerged. With relativity, there are several times that, undoubtedly, correspond (...) but that do not retain absolute duration. The duration is relative." (Bachelard quoted by Gurvitch 1986 (1968), 378-379). From this perspective, in his essay "The multiplicity of social times"(1986 [1968]), Gurvitch constructs a typology of eight different social times ${ }^{7}$. For example, it defines "cyclical time" as the time in which the past, present and future are projected mutually among themselves (emphasizing continuity and the reduction of contingency) and "creative or explosive time" as the time that dissolves the present, much like the past, creating the future that is immediately exceeded, a time of revolution that "when it is effective, makes life dangerous for the global and partial structures that move within it, because it involves the most risk and requires maximum effort" (ob. cit.: 388 ).

Paradoxically, this relativistic perspective of time currently has its nucleus in an amplification of present time (even upon past times), permitted by a globalization (in the network) in "real time", that intensifies new kinds of intersubjectivity promoted by "simultaneity", "immediacy", "the ephemeral", "volatility", and the "uncertainty of time and space" (Adam 2003:74). The anthropologist Johannes Fabian referred to this process in "Time and the Other - How anthropology makes its object" (2003 [1983]) when he described the need for anthropology to recreate a new model for interpreting the Other. In this model, the Other would be positioned

$6 \quad$ In Levi-Strauss's expression: “(...) the intrinsic value attributed to the myth that comes from the fact that these events, which supposedly take place in a moment of time, also form a permanent structure. This structure relates both to the past, present and future" (Levi-Strauss, in Carmo, 2006).

7 They are presented by the author: 1) the time of long duration and retardant time, 2) the time of illusion when, under apparent calm, sudden crises are being prepared - the time of surprise, 3) the irregular time between the appearance and disappearance of rhythms or the time of uncertainty, 4) the cyclical time of movements in the same place, 5) time delayed in relation to itself, 6) the time alternating between delay and advancement, 7) the time ahead of itself, and 8) the explosive time of creation. 
in the same time as the observer, i.e., an intersubjective time, and not (as was the case) as if the Other belonged to another time (in the past), defined as "archaic", "primitive", "mythical", "ritual" or even "tribal". This perspective, which Fabian called the "time-machine" of anthropologists, reflects, for the author, a denial of "coevalness" or "intersubjective time", of the sharing of the same present time (2003 (1983): 32), which indicates an ethnocentric and colonialist approach.

However, today various authors make reference to this "intersubjective time" as a mixture of times. Canclini (2001) refers to "strategies for entering and leaving modernity" where "traditional" and "modern" practices are diluted. Radicalizing this idea, Latour (1993) states that "we have never been modern" . Appadurai also mentions that "pastiche" and "nostalgia" are essential modes in the production and reception of the images of late capitalism. In his words: "The Americans themselves are no longer well in the present when they stumble on the megatechnologies of the twenty-first century with the garb of sixties film noir, fifties dining, forties fashion, thirties houses, twenties dances and so and so on, ad infinitum"(2004 (1996): 47).

Thus, this cyclical approach to the dynamics of socio-cultural change seems to be based on an organic conception of social dimensions that is structured by the cultural dimension and is driven by an "archivistic" compulsion where everything can somehow be recorded, repeated, ritualized and recycled. And, therefore, in contrast to what Newton said, the "flow of time" seems to depend more and more on external and cultural factors.

All these authors see repetition as a cross-section of life in all its spheres, from art, myth and ritual to daily life. This suggests that the construction of meaning is actually a type of social remembering (Connerton 2003 [1989]), which is emphasized today by the globalization of the spread of real-time information. As Appadurai states: "The past is no longer a homeland to return to in a simple memory operation. It has become a synchronic storage of cultural scenarios, a kind of temporal central depository to turn appropriately, as in the case of the film to show, the play to stage, the hostages to save" (2004 (1996):47).

In a context of "structural hybridism" where there is an intensification and compression of time and space that generates a kind of "eternal present", or "continuous present" in the terms of Castells (2000 [1996]) or Virile (1995), apparently this perspective better reflects both the excess of ephemerality and the excess of repetition/mimicry produced by the amplification of cultural (and visual) contacts. The intentional and creative performance of repetition can even be seen as a translation of reflexivity where memory of the past faces the present and future. This reflexivity seems to be accentuated in times of crisis, when participation in art becomes an alternative to engaging in politics. By means of art, people "will be able to act in another way" (Giddens 2000:87) - in a form of action that not only implies reflexivity but also the variability necessary to find non-codified solutions within already known effects.

\section{HYBRIDITY, MIMESIS, PERFORMATIVITY AND REFLEXIVITY}

In her book Unmarked, Peggy Phelan applies the notion of presence and the interaction of the object and the receiver as the lowest common denominator in the notion of performance.

$8 \quad$ See note 2 . 
She uses presence to analyse "things" as diverse as photographs, paintings, films, theatre, political protests and performance art. This "expanded field of performance" (Phelan 2006:4) has grown not only through an increase in the hybridization between the art world and the social, which generates more and more hybrids or unclassified objects, but also through an expansion of the concept of social performance, which in contemporary society has become increasingly operationalized as a value for measuring: we measure social performance and rank through social performance. Performance, from this specific social perspective, becomes an engine that governs all aspects of social relations, from their most public expression, in work and leisure, to their most private expression in the individual's personal life. This process has led various authors to state that (social) performance is the "new ideology" (Heilbrunn 2004:6) of contemporary society.

The expansion of the concept of performance seems, then, to be considered on a scale positioning - in an inverse correlation - a notion of social performance, predominantly associated with a hierarchy of value and its visibility, and a notion of performance art, which criticises this idea. The history of the latter notion is given through a continuous return to the present in various "artistic movements", which has intended to produce an artistic re-connection of art with social issues, from romanticism to realism, performance, happenings, fluxus, situationism, etc.

And so, even if one of the factors that characterize performance art is its ephemerality - Phelan tells us that the performance only exists at the present time and is "representation without reproduction" (2006), as each performance is a unique event that connects with a notion of linear and irreversible time - it is nevertheless true that, as a social dynamic of reflexivity, performance art has been retrieved cyclically. Performance art exists only now, yet it also exists now, before and again in new relationships of art with the social context.

In contemporary times, given the current space-time compression, these cycles of retrievability/repeatability have been compressed and speeded up. As Rosalee Golberg writes in Performance Art:

In the past, the history of performance art has appeared as a series of waves; it has come and gone, sometimes seeming rather obscure or dormant while different issues have been the focus of the art world. When it has returned, it has looked very different from its previous manifestations. Since the 1970s, however, its history has been more continuous; rather than giving up performance after a short period of lively engagement (...), numerous artists (...) have worked exclusively in performance (...). Yet, (...) performance art continues to be a highly reflexive, volatile form that artists use to respond to change. (...) performance art continues to defy definition as unpredictable and provocative as it ever was (2001 [1979]:226).

This unique, ephemeral, yet recycling nature of performance art (which, as a social dynamic, has become recurrent), is demonstrated by expressions like the "return to the real" (Foster 2001) or the "social turn" (Bishop 2006) in art" or, again, "re-enactments" by the precursors of performance art (who seem to fuse the ideology of social performance with re-performance via repeatability and visibility, in museums such as MoMA or the Guggenheim, e.g. Marina Abramovic). It may, however, be given another dimension when discussed in the light of the analysis developed by Michael Taussig. He has noted that the core element of social performance

9 A process that Herbert Blau had already referred to when, in the essay "Universals of performance; or amortizing play", he said: "There has been a serious effort over the last generation to eliminate the as if, to return performance to unmediated experience" (1989: 253). 
is the repetition factor and not the singularity. As his starting point he takes an excerpt from Walter Benjamin's 1933 essay “On the Mimetic Faculty", in which Benjamin asserts the human compulsion to produce similarities and behave like the Other ${ }^{10}$. In his book Mimesis and Alterity (1993), Taussig carries out an ethnographic analysis of the social performances of the Cuna tribe, how they have absorbed and adapted colonial symbols as their own. For him, the "mimetic faculty", which is always a sign of otherness, should not be seen as a historical continuity but as one that allows a cyclical revival of the re-juxtaposition of the very old with the very new.

This perspective is based on the idea that contact and copying merge to become virtually identical. As Benjamin puts it: "Seeing something or hearing something is to be in contact with that something" (quoted by Taussig 1933:21) and could lead to the reproduction of that something. A similar process was analysed in 1938 by Roger Caillois in his "Mimicry and Legendary Psychasthenia”. Caillois justifies mimicry, beyond survival issues (defence and aggression), with the fascination of similarity, sometimes purely aesthetic (1981[1938]: 84-119). The difference sought by hybrid art is strongly based on this idea of wonder at and fascination with the different. For this reason, paradoxically, the mimetic reproduction of this difference can produce a hybrid mimesis, a sameness ${ }^{11}$.

Another explanation for this mimesis can be found in one of Victor Turner's last writings, "Body, Brain and Culture" (1988), where the author argues that social rituals (and their maintenance) can be explained by a collective archetypal pattern produced neurophysiologically in the human brain. For Turner, Jungian archetypes reflect a kind of repertory of a priori categories, ideal types of representations of myths, rituals and collective symbols that are subjectivated through new empirical facts. In quasi-similar circumstances these produce quasisimilar responses.

Our globalised times, being based on "mediascapes" (Appadurai 2004 (1996): 54) that provide extensive and complex repertoires of images and ideas to audiences around the world, allow a kind of "total viewing" where everything (including the past) becomes contemporary, a "continuous present" dominated by "pastiche" and "nostalgia" (Calabrese, 1999 (1987): 194). Such "mediascapes" enable us to consume and recall examples from the past, by providing immediate access to internet files on more critical and reflective artistic practices such as performance art, as well as the risks of both the present and the future, by calling attention to the need for a more sustainable life (which today includes not only the ecological but also the cultural, economic and social dimensions). Authors such as Kagan and Volker call this the "new

10 The author writes: "Nature creates similarities. One need only think of mimicry. The highest capacity for producing similarities, however, is man's. His gift of seeing resemblances is nothing other than a rudiment of the powerful compulsion in former times to become and behave like something else. Perhaps there is none of his higher functions in which his mimetic faculty does not play a decisive role" (Benjamin, quoted by Taussig, 1993: 19).

11 A process that relates to the issues advanced by Pnina Werbner. This author says that, though "it makes sense that hybrids are perceived endowed with unique powers, good or evil, and that hybrid moments, spaces or objects are hedged in with elaborate rituals, and carefully guarded and separated from mundane reality" (2000: 1), we must ask: "what if cultural mixings and crossovers become routine in the context of globalization trends? Does that obviate the hybrid's transgressive power? And if not, how is postmodernist theory to make sense, at once, of both sides, both routine hybridity and transgressive power? Even more, what do we mean by cultural hybridity when identity is built in the face of postmodern uncertainties that render even the notion of strangerhood meaningless" (idem). 
frontier of contemporary art" (2008). In such times as these, the configuration is set for a return to performance art based on a reflection on the real or social.

These "returns" of performance art in times of economic and political crisis may be explained in two ways. The first is as a product of this "nostalgic consumption" (which as any consumption tends toward repetition and habituation) that can potentially recreate "simulacra periods that constitute the flow of time, conceived as lost, missing or distant" (Appadurai 2004 (1996): 111). The second is as a reaction to mass consumption and capitalism ${ }^{12}$, that is, as a central process for ensuring a more organic and inclusive social performance in the public sphere, in the search for a "re-fusion" of performance (Alexander 2006) or a "reintegration" phase of Turner's social drama (1988:76). These "returns" call for active citizenship, where mimesis and bybris, or "habit" and "improvisation" (Appadurai ob. cit.: 19) compete. This active citizenship provides a better justification for associating the concept of participation in art with the political dimensions of the concept of participation, which are operationalized through more classical ideas such as representation and community or more recent notions such as sustainability and participatory democracy. It is this incorporation that allows artistic participation in which the nucleus is no longer "objects" but the "issues" themselves of the social sphere (Milevska 2006). In this view, performance art and participatory art may become an alternative power to politics itself ${ }^{13}$, a parallel polis, a civil power of citizen engagement and intervention, operating within civil society and beyond the authority of the state.

\section{An example of the "return" of performance (social) art: between Portugal and the WORLD AND VICE VERSA, AND BETWEEN HYBRIS AND MIMESIS}

In a film interview carried out as part of the exhibition "Uncertain Concept" in December 1974, the Portuguese experimental poet Ernesto de Melo e Castro referred to the importance of artistic laboratory research, research he considered as important as science. Melo e Castro said that on April 25 (date of the Carnation or April Revolution in Portugal) this laboratory had leapt onto the street! In his words: "If, before 25 April, many of us visual poets were dedicated to laboratory experimentation that was somewhat hermetic and closed to the public, it was because the context prior to April 25 was disconnected from the creativity of men and women."

Walking in the Portuguese streets after the revolution, Melo e Castro showed how the Revolution had opened the doors to the manifestation of the people's creativity. This was revealed in the graffiti that appeared on the walls and even the road signs: for example, the word "fascism" was added to the wording on the stop sign; the abbreviation of the P.C.P. (Portuguese Communist Party) was transformed into BOB (meaninglessly), and the acronym CDS (Popular

12 As Appadurai mentions, the consumption of mass communication causes, in the whole world, resistance, irony, selectivity and, generally, an impulse for action (2004 (1996): 19).

13 In the political field, therefore, there are various factors that may help to explain this expansion in the concept of artistic participation: from the crisis in the legitimacy of the state to the claims of the actors (seeking to take in groups that are generally excluded from participation or representation) and on to the complexity itself of the social problems and the diversity necessary for decision-making. In general terms, these factors may be included in the emerging paradigm of participation that is based on a re-interpretation of representative democracy and the need to complement it with participatory democracy, and perhaps extend it (Guerra 2006; Fung and Wright 2003; Dryzek 1990). 
Conservative Party) had the "S" replaced by “\$”. These additions, destroying univocal meaning, were actually a performance of political change.

This explosion of popular creativity on the streets of post-April 25 Portugal extended an artist's creativity to the common man. It was also complemented by a kind of artistic activity that was looking for a relationship with the society through the construction of artistic murals, or a "museum funeral" - like the Soares dos Reis Museum "funeral" (1974) in Oporto. Ana Hatherly's film "Revolution" (1977), created from the posters and graffiti that the artist encountered on the streets of Lisbon, by mixing them with the sound of political slogans and political music, also reflects this environment. Before April 25, no one dared to write on walls or put up posters. To see the city's spaces so used, so full of graffiti and posters, was a representation of the voice of the people, of their revolt against fascism ${ }^{14}$.

It was precisely this fusion of the art environment with the social that led the historian and art critic João Pinharanda to characterize April 25 as the first example of anti-monument public art in Portugal. According to him, this was a moment of collective creation and participation, and of popular street action following the fall of the regime, through a simultaneous process of destroying the symbols of the regime (including public sculptures) and raising an alternative provisional iconography on city streets, consisting of paintings, graffiti and posters (2005:41).

The creativity that spread to the street in Portuga ${ }^{15}$ was part of a global process that emerged in the 60s, when the street became the site of artistic practices, from Debordian situationism in Paris to the graffiti in New York. This was the time that the French, in their revolutionary struggle against the alienation of leisure, created their "situations", making everyday life into a "theatre of operations" and insisting that art should be "the language of communication" (Debord quoted by Jappe 2008 [1993]: 92). And in New York a

huge amount of art (...) in many genres was being produced at the same time, on the topic of the street and, sometimes, directly on the street. (...) And, meanwhile, a multitude of street performers were playing instruments or singing music of all kinds, dancing, performing or improvising plays, creating happenings, environments and murals, and saturating the streets. (...) Many of the manifestations and confrontations of the 60s have become notable works of kinetic art and environmental art, in whose creation millions of anonymous people participated (Berman 1989: 345-346) (author's translation from Portuguese version).

Today, in many cases, the artistic interventions that seek a relationship with the social are recovering this participatory ${ }^{16}$ and performative effect, to express their "yelling in the street". A concrete example, among others, is the work of Hugo Canoilas, a young Portuguese artist. One of Canoilas' recent works, which was included in the "People" exhibition at the EDP Foundation (2010) in Lisbon, was a large white wall composed of sentences referring to the people (written by national and international authors such as Sophia de Mello Breyner Andersen, Thomas

14 Phone conversation with the artist in October 2010.

15 For a more detailed analysis of this topic, see also the book Art and Revolution (Couceiro 2004).

16 Several cultural programs began to make use of the problematic of artistic participation in Portugal. Examples include Lisboa Capital do Nada (Lisbon Capital of Nothing)(2001), a program of public art developed by the association Extra]muros[; O Estado do Mundo (The State of the World) (2006/2007) and Próximo Futuro (Next Future) (2009-2012) from the Calouste Gulbenkian Foundation; the initiatives of the cultural organizations Alkantara and ZDB, Cidade Ideal (Ideal City) (2007), and the Maria Matos Theatre, Procuram-se Manifestos (Wanted Manifestos), linked to the project Choir of Wills, and Noite do Manifesto (Manifesto Night) (2012), all in Lisbon; and an alternative program in Oporto, "A Sala" (The Room) (2006 ...), which was mounted without state support. 
Bernhard, Mário Cesariny, Guerra Junqueiro, Grupo Krisis, Augustina Bessa Luís, Almada Negreiros, Friedrich Nietzsche, Eça de Queirós and Oscar Wilde, to which Canoilas added some anonymous sentences and some words of his own). Overnight, after dismantling the exhibition, the artist clandestinely "installed" parts of the mural in middle-class residential streets, leaving anonymous messages about the people and their constraints to be seen.

Another project, Jornal Mural (Wall Journal) (2010), one of collective collaboration in which Canoilas also participated, resulted in an ephemeral newspaper "pasted" on the walls of Lisbon. Its goal was to establish itself as an artistic intervention and political challenge to an urban audience with "news of something that happened though nobody saw it or that was not witnessed in its totality", which would result in "a supply/offer of intellectual capital to be shared by an active community".

These actions combine the transgression codes of the carnival and terrorism (Remshardt 2004:58), or guerrilla warriors: the texts of this art secretly invade the public space, taking it as a "discussion forum", where art can lay the foundations for the creation of a "common language" (Martin 2004), the basis of a script (Alexander 2006:33) that can mobilize action leading to civic and political change.

This performative feature has its background in one of the most important representatives of Greek Cynicism, the philosopher Diogenes of Sinope, who, in the third century BC, decided to sleep in an empty barrel and have a cup as his only property, a sign of protest against the opulence and corruption of Athenian society. During the day, he walked about with a lantern looking for a single reasonable person. But in Canoilas' art this performative form exists without the artist's presence.

This form of artistic action belongs to what Turner called culture's "subjunctive" mood, which is expressed by scenarios of supposition, desire, hypothesis and possibility (1988:101). Or this kind of art may be better described by Irit Rogoff and Florian Schneider's notion (2008) of "productive anticipation" - a notion that attempts to characterise a state that is simultaneously reflexive and participatory, not formatted or speculative (in the sense that it does not try to give viewing instructions or set out predefined ways of seeing). This kind of anticipation is endowed with a strong performing potential - which, when successful, may even create "social fictions" that serve alternative and more inclusive scenarios, both subverting and transforming the prevailing reality.

In a contemporary context that is beginning to debate the existence of globalized art, Hugo Canoilas' work thus exhibits one of the features of our time: the return of performative art in the public space, though, in this process, it not only applies mimesis but also our contemporary bybris of a growing demand for sustainability ${ }^{17}$. This trait is mirrored in the performativity and recycling of the materials that make up the pieces of "People", poor materials that are re-used for various purposes (doors and wood scraps are now screens), as well as in the mutability of the sites that host them. In this case, these pieces left the museum's exhibition space for the street, in a multifocus mode, as is characteristic of "direct theatre" (Schechner, 1995:88). They were left at the mercy of those who wanted to take them home.

17 Note also that many of the civic movement's antecedents occurred in the 60s and 70s. See the book edited by T.V. Reed, The Art of Protest - Culture and Activism from the Civil Rights Movement to the Streets of Seattle (2005). 
A little while after these art installations, the streets of Lisbon (like the streets of the whole world) witnessed a return of civic events such as the demonstrations of the "Geração à Rasca" ("Precarious Generation") (12 March 2011), "May Day" (1 May 2011), the "Indignados" ("Outraged") (15 October 2011), the "Greve Geral" (General Strike) (22 March 2012) and "Que se lixe a Troika! Queremos as nossas vidas" "To hell with the Troika! We want our lives" (15 September 2012). This gave visibility to the precariousness and ungovernability existing in Portugal and the world, through the intensive use of an aesthetic, civic and political quasicarnival and the use of masks, songs, hymns, etc. (Cohen 1993). In fact, these social protest movements have their models in anti-war or anti-globalization demonstrations, "Pride Paredes LGBT", or even the political campaigns/airtime of the Bloco de Esquerda (Left Bloc), among others that emerged in Portugal in the late twentieth and early twenty-first century. They reveal new forms of political expression that can be analyzed in the context of performance theory. As Eyerman mentions (2006:207), this analysis may be carried out on the general mise-en-scène of those new social movements (often with nonpartisan status and without stable leaderships or even a decent organization), on the basis of scenery, frame, stage, script, performers and reception, and factors such as "presence" and "corporality", "acting" and "acting out", "the role of drama and the symbolic in movement activity", "the performance of opposition", "the aesthetics of movement", the "choreography of protest", and "the tension between the expressive and the strategic".

In Portugal, these demonstrations have appropriated global icons, such as the systematic use of masks, as in the case of the Anonymous masks under the slogan "Anonymous changing the world"; the masks to imitate the politicians targeted by the protests; the oxygen masks used with the poster slogan "unbreathable until when?"; and the mask-wearers in black clothing, carrying black flags and posters saying "Unmask democracy". But local historic memories are also being recovered, doing justice to the statement by Diana Taylor, whose "performances travel, challenging and influencing other performances. Yet they are, in a sense, always in situ" (2007 [2003]:3). In the Portuguese case, these demonstrations have their ideas inscribed in the script of April 25, making use of the idea that "a new April 25 is needed in Portugal"18, of the words used at that time such as "The people united will never be defeated", of music with systematic recourse to Zeca Afonso's songs, or even of the participation of the Portuguese comedians Os homens da luta (The men of the struggle). In the demonstration "Geração à Rasca" "Precarious Generation"), they sang, in an open van, "Struggle is Joy" and the slogan "Fight, fight, fight, comrade, fight", the song that won the Eurovision Song Contest in Portugal (with the votes of the TV audience) and was performed in Germany for the Eurovision Song Contest (2011). The national anthem was also sung repeatedly. This framework implies an understanding of past as a "debate" (Appadurai 1981) and culture as a "process" (Hannerz 1997). In Hannerz words: "To keep culture in motion, people, as actors and networks of actors, have to invent culture, reflect on it, experiment with it, remember it (or store it in any way), discuss it and transmit it" (1997:12).

Another trend in these demonstrations, as in the case of the demonstration "To hell with the Troika! We want our lives", is that they are increasingly seeking to be an unmediated expression of the needs and ideals of the common citizen: in terms of leadership and mobilization of the population that opposes or resists the political or trade union leadership; in terms of the number

18 It may be noted that on 9 July 2008, the Teatro Ligna presented a public radiophonic performance under the title 'In Search of the Lost Revolution', with great attendance in the streets by the Portuguese, although this 'demonstration' had an artistic character of entertainment. 
of participants (the latest demonstrations (2012), spread over 40 cities around Portugal, were attended by people who had never participated in a demonstration or who have not participated in one since 1974/75); in the form of participation, with many ordinary people climbing onto an improvised stage, a sort of Speakers' Corner, to make their voices and discontent heard; and also in the level of emotion - with complex nuances of sadness, euphoria, tears, frustration and anger. This meant that in a demonstration characterized by passivity, tomatoes, eggs and bottles were thrown at the places making up the map of authority (parliament, the IMF building in Lisbon, etc.), and a young man immolated himself.

A few days later (September 30, 2012), “Colectivo Negativo”, a group of artists working with installations and street art performances besieged the Assembly of the Republic with small plastic toy soldiers that had been glued to the ground. This "march of the soldiers" retrieved the slogan used by Salgueiro Maia, the "Captain of April" in the 1974 revolution: "We are all in command, we are all captains!" Then, on October 10, a "cultural demonstration" was organized by all kinds of Portuguese artists on various stages throughout the country. They wanted to show that they too felt: "To hell with the Troika! We want our lives".

In this new period of social movements, the use of digital media technology and virtual communication networks has also become an instrument to disseminate performative messages with political slogans and information on discussion forums, using viral spam methods with obvious ideological or artistic traits. Posters, photographs and videos proliferate, as well as a whole visual culture of a political nature that spreads through social networks such as blogs, Facebook, Twitter, etc., or multiple digital platforms such as YouTube and Vimeo.

In parallel, there is the political propaganda of, for example, certain small parties like the Bloco de Esquerda (Left Bloc), with their placards containing a comic-strip figure and the slogan, "Don't steal, the banks don't like competition", or the new pseudo-parties such as "my beloved country". This political propaganda is spread about the streets of the city, referring us to blogs, in a process that resorts to a rhetoric close to the performativity of the social movements.

Once again, the walls of the cities have hosted various claims. For example, the slogan "What I want is a revolution!" was written twice on the walls of a university institution, in the summer of 2011 and early in the spring of 2012. The writing did not last long on either occasion as it was erased from the university walls and merely the performative memory remained. They have also hosted a range of graffiti or quasi-artistic expression in a spiral dialectic of "social drama" and "aesthetic drama" that, as emphasized by Turner and Schechner, refers to a matrix mirror (rather than a planar one), where art produces a reflexive meta-commentary and even anticipation of a social crisis, and the social is aestheticized to better convey a political message. In Victor Turner's words: "The result is not an endless cyclical repetitive pattern or a stable cosmology. The cosmology has always been destabilized, and society has always had to make efforts, through both social dramas and aesthetic dramas, to restabilize and actually produce cosmos" (1989: 16-18).

This idea of a "return" to a direct approach to street art emphasizes the notions of excess, appropriate to a selection and affirmative creation, as Nietzsche says. This excess is an inherent attribute of the mutability promoted by hybridity. But at a time of "structural hybridity", promoted by an intensification of exchanges between all spheres of society (cultural, social, economic and political) and all regional levels (local, regional, global and translocal), the very 
performativity of hybrid mimesis or mimetic hybridity, at its most ephemeral and most recurrent, most different and most similar, is accelerating. Portuguese art follows the same process as the rest of world - hence the cycle to register a performance (social) art that seeks to intervene reflexively and performatively in the social, in which periods ${ }^{19}$ of crisis seem to be equivalent, in a specific script, to periods of rebellion and revolution. Does that mean we already know the rest of the story recorded in this script?

\section{References}

Adam, Barbara. 2003 "Reflexive Modernization Temporalized". In Theory, Culture E Society. Vol. 20 (2), 59-78. London, Thousand Oaks, CA and New Delhi: Sage Publications. 2006 “Time”. In Theory, Culture E Society. Vol. 23 (2-3), 119-138. London, Thousand Oaks, CA and New Delhi: Sage Publications.

Alexander, Jeffrey C. 2006a "Cultural Pragmatics: Social performance between ritual and strategy". In Social Performance - Symbolic Action, Cultural Pragmatics and Ritual. Edited by Jeffrey C. Alexander, Bernhard Giesen, Jason L. Mast, 29-89, Cambridge: University Press.

Alexander, Jeffrey C. 2006b The Civil Sphere. Oxford: University Press.

Appadurai, Arjun. 1981 “The past as a scarce resource”. In Man(N.S), 16(2), 201-219. 2004 (1996) Dimensões Culturais da Globalização. Lisbon: Teorema.

Atkins, Robert. 2008 "Politics, participation, and meaning in the age of mass media". In The Art Of Participation, 1950 to Now. Edited by Rudolf Frieling et al., 51-65, San Francisco Museum of Modern Art: Thames \& Hudson.

Baktin, Mikhail. 2004 (1981) "Forms of time and chronotope in the Novel", 84-258, In The Dialogic Imagination. Edited by Michael Holquist, Austin: University of Texas Press.

Berman, Marshall. 1989 Tudo o que é Sólido se Dissolve no Ar. Lisbon: Edições 70.

Beck, Ulrich; Giddens, Anthony; Lach, Scott. 2000 Modernização Reflexiva - Politica, Tradição e Estética no Mundo Moderno. Oeiras: CELTA.

Bishop, Claire. 2006 "The Social Turn: collaboration and its discontents”. In Artforum, 179-185. Blau, Herbert. 1989 "Universals of performance; or amortizing play". In By Means of Performance. Edited by Richard Schechner and Willa Appel, 250-272, Great Britain: Cambridge University Press.

Caillois, Roger. 1981 [1938] “Mimétism et Psychasthénie Légendaire”. In Le Mythe et L'Homme. 84-119, Paris: Galimard.

Calabrese, Omar. 1999 (1987) A Idade Neobarroca. Lisbon: Edições 70.

Canclini, Néstor García. 2001 (1990) Culturas Hibridas: Estratégias para Entrar y Salir de la Modernidad. Barcelona: Editorial Paidós.

Carmo, Renato. 2006 Contributos para uma Sociologia do Espaço-Tempo. Oeiras: CELTA.

Castells, Manuel. 2000 (1996) The Information Age: Economy, Society and Culture. Vol. I. The Rise of the Network Society. Oxford: Blackwell.

Cohen, Abner. 1993 Masquerade Politics - Explorations in the Structure of Urban Cultural Movements. Oxford, Providence: Berg Publishers Limited.

Connerton, Paul. 2003 (1989) How societies remember. United Kingdom: University of Cambridge.

19 Defined by Bakhtin [2004(1981):84]) as "chronotopes", in the literal sense of "time space". 
Couceiro, Gonçalo. 2004 Artes e Revolução,1974-1979. Lisbon: Livros Horizonte.

Deleuze, Gilles. 2000 (1969) Diferença e Repetição. Lisbon: Relógio de Água.

Dryzek, John S. 1990 Discursive Democracy - Politics - Policy and Political Science. Cambridge:

Cambridge University Press.

Eco, Umberto, et al. 2004 (1974) La Nueva Idade Média. Madrid: Alianza Editorial, pp. 9-35.

Eagleton, Terry. 2000 The Idea of Culture. Oxford: Blackwell Publishers.

Eliade, Mircea. 1969 Le mythe de l'éternel retour: Archétypes et repetition, Paris: Gallimard.

Eyerman, Ron. 2006a "Performing opposition or, how social movements move". In Social Performance - Symbolic Action, Cultural Pragmatics and Ritual. Edited by Jeffrey C. Alexander, Bernhard Giesen, Jason L. Mast, 193-217, Cambridge: University Press.

Fabian, Johannes. 2003 (1983) Time and The Other - How Anthropology Makes its Object. New York, Chichester, West Sussex: Columbia University Press.

Foster, Hal. 1999 The Return of the Real. Cambridge, London: The MIT Press.

Fung,Archon; Wright, Eric Olin. 2003 “Thinking about Empowered Participatory Governance”. In Deepening Democracy - Institutional Innovations in Empowered Participatory Governance. Archon Fung and Erik Olin Wright (Eds.), 152-375, London, New York: Verso.

Giddens, Anthony. 1986(1984) The constitution of society: outline of the theory of structuralism. Oxford: Polity Press.

Golberg, Roselee. 2001 (1979) Performance Art - From Futurism to the Present. New York: Thames \& Hudson.

Guerra, Isabel C. 2006 Participação e Acção Colectiva - Interesses, Conflitos e Consensos. Estoril: Princípia.

Gurvitch, Georges. 1986 (1968) A Vocação Actual da Sociologia. Vol.II (XIII), 367-487. Lisbon: Edições Cosmos.

Kagan, Sacha; Kirchberg, Volker. 2008 Sustainability: A New Frontier for the Arts and Cultures. Frankfurt: VAS, 108-146.

Kern, Stephen. 2003 (1983) The Culture of Time and Space - 1880-1918. United States of America: Harvard University Press.

Hannerz, Ulf. 1997 "Fluxos, fronteiras, híbridos: palavras-chave da antropologia transnacional”. Revista Mana, 3 (1), 7-39.

Heilbrunn, Benoît (org.) 2004 "Introduction: (Re-)penser la performance". In La Performance, une nouvelle idéologie? Paris: Éditions La Découverte, 5-12.

Jappe, Anselm. 2008 Guy Debord. Lisbon: Antígona.

LACY, Suzanne. 1996 "Cultural Pilgrimages and Metaphoric Journeys". Mapping the Terrain - New Genre Public Art. Edited by Suzanne Lacy, 19-47, Seattle, Washington: Bay Press.

Latour, Bruno. 1993 We have never been modern. Translated by Catherine Porter. Cambridge: Harvard University.

Maffesoli, Michel. 2001 O Eterno Instante - O Retorno do Trágico nas Sociedades Pós-modernas. Lisbon: Instituto Piaget.

Madeira, Cláudia. 2010 Híbrido. Do Mito ao Paradigma Invasor? Lisbon: Editora Mundos Sociais.

Martin, Bradford. 2004 The Theatre is in the Street. USA: University of Massachusetts Press.

Merton, Robert. 1985 (1965) On the Shoulders of Giants. San Diego, New York, London: Harcourt Brace Javanovich Publishers.

Milevska, Suzana. 2006 Participatory Art - A paradigm shift from objects to subjects, http://www. springerin.at/dyn/heft_text.php?lang=en\&textid=1761

Taussig, Michael. 1993 Mimesis and Alterity - A Particular History of the Senses. New York, London: Routledge. 
Pieterse, Jan Nederveen. 2001 "Hybridity. So what? The anti-hybridity backlash and the riddles of recognition". In Theory, Culture E' Society, 18 (2-3), 219-245. London, Thousand Oaks and New Deli: SAGE.

Pieterse, Jan Nederveen. 2001b "Global Multiculture". Futures:1-16.

Pinharanda, João. 2005 "Monumentos em Lisboa de 1974 aos nossos dias: enquadramento teórico, político e urbano”. In ArtePública - Roteiro Estatuária e Escultura de Lisboa, 40-47, Lisbon: Câmara Municipal de Lisboa - Pelouro da Cultura.

Reed, T.V. 2005 The Art of Protest - Culture and Activism from the Civil Rights Movement to the Streets of Seattle. Minneapolis, London: University of Minnesota Press.

Remshardt, Ralf E. 2004 Staging the Savage God - The Grotesque in Performance. USA: Southern Illinois University.

Rogof, Irit; Schneider, Floran. 2008 "Productive Anticipation”. In Cultural Politics in a Global Age - Uncertainty, Solidarity, and Innovation. Edited by David Held and Henrietta L. Moore, 346-357, Oxford: OneWorld.

Schechner, Richard. 1995 "Introduction - Jayaganesh and the avant-garde". In The Future of Ritual - Writings on Culture and Performance. Edited by Richard Schechner, 19-21, London and New York: Routledge.

1995 "The Street is the Stage". In The Future of Ritual - Writings on Culture and Performance. Edited by Richard Schechner, 45-93, London and New York: Routledge.

Sorokin, Pitirim. 1962 Dinâmica Social e Cultural. Madrid: Ed. Instituto de Estúdios Políticos. 1957 Social E Cultural Dynamics: a study of change in major systems of art, truth, ethics, law and social relationships. Boston: Porter Sargent.

1969 Novas Teorias Sociológicas. Porto Alegre: Editora Globo. 1928 Contemporary Sociological Theories. New York: Harper \& Brother.

Stross, Brian. 1999 "Theorizing the Hybrid". In The Journal of American Folklore, Vol. 112, No. 445: 254-267.

Taylor, Diana. 2003 The Archive and the Repertoire - Performing Cultural Memory in the Americas. Durham and London: Duke University Press.

Turner, Victor. 1988 The Anthropology of Performance. New York: Paj Publications. 1989 "Are there universals of performance in myth, ritual, and drama?" In By Means of Performance. Edited by Richard Schechner and Willa Appel, 8-18, Great Britain: Cambridge University Press.

Virílio, Paul. 1995 La Vitesse de libération. Paris: Éditions Galilée.

Werbner, Pnina. 2001 Debating Cultural Hybridity - Multi-Cultural Identities and the Politics of Anti-Racism. London \& New Jersey: Zed Books. 